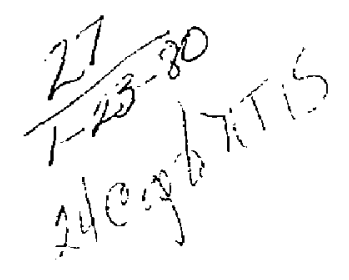

CLIMAX GHANITE TRST RESULTS

\section{MASTER}

$x^{2}$
UCID- 18502

L. D. Remspott

January 15,1980

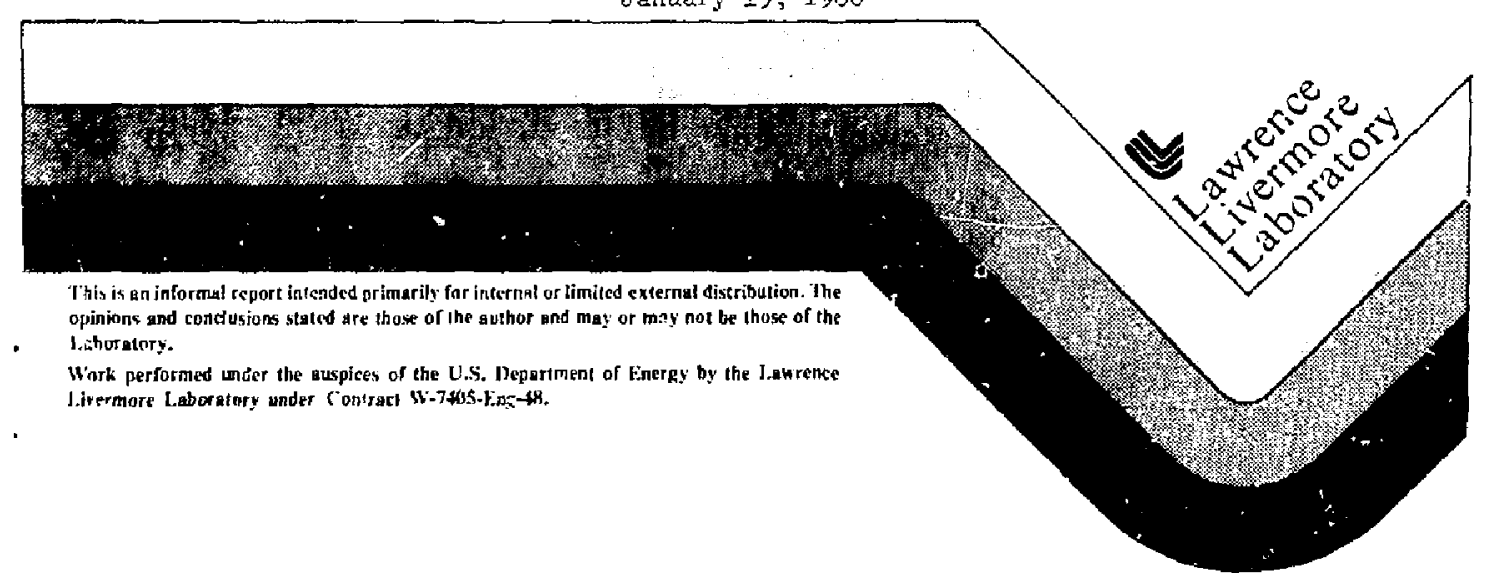

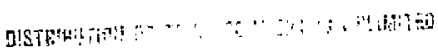


UCID-18502

CLIMAX GRANITE TEST RESUITS

L. D. Ramspott

Manuscript date: January ]5. 1980

Reprinted from Proceedings of a Workshop on Thermomechanical Modeling for a Herdrock Waste Repository, Berkeley, Califolnia, June 25-27, 1979, Lawrence Livermore Laboretory Report UCAR-10043 


\title{
CLIMAX GRANITE TEST RESULTS
}

\author{
L. D. Ramspott \\ Unfversity of California \\ Lawrence Livermore Laboratory \\ Livernore, California
}

\section{INTRODUCTION}

The Lawrence Livermore Laboratory (LLL), as part of the Nevada Nuclear Waste storage Investigations (NNWSI) program, is carrying out in situ rock mechanics testing in the Climax granitic stock at the Nevada Test site (NFS). Altbough LIL is heavily involved in planning and execution for a test storage of spent reactor fuel in the climax granite ${ }^{1}$ and in the planning and design for a Rock Mechanics Test Facility, this summary will address only those field data taken to date that address thermomechanical modeling for a hardrock repository. The results to be discussed include thermal measurements ir. a heater test that was conducted from October 1977 through July 1978, and stress and displacement measurements made during and after excavation of the canister storage drift for the Spent Fuel Test (SFT) in the climax granite. Associated Iaboratory and field measurements will be sumarized.

\section{HEATER TEST RESULTS}

\section{Deseription of Test Layout}

Heater Test Ho. I was designed to be a simple temperature measurement test to obtain in situ values for thermal conductivity and diffusivity for use in subsequent scoping calculations, and to screen for gross or unexpected effects from the heater. After initial testing, modifications were made to some of the field instrunentation to allow permeability measurement as a function of rock temperature. No stress or displacement measurements were attempted. Figure $I$ shows the layout of Heater Test wo. 1 and Fig. 2 shows a crosa-section along the drift array (identical to the alcove array). This 
layout was selected such that the two ingtrumentation Ilnes were orlented parallel and perpendicular to the principal near-vertical fracture orientation at the test location.

The heaters were 16-mm-diam, Inconel-clad, standard-carirldge-'sype immersion units. The 3-m-long heaters were centralized in 49-mm-diam noles, and

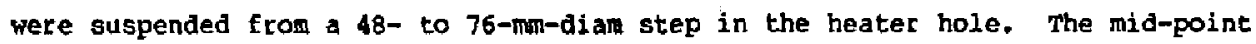
of the heater was $7.5 \mathrm{~m}$ below the drift surface, well beyond mining or other

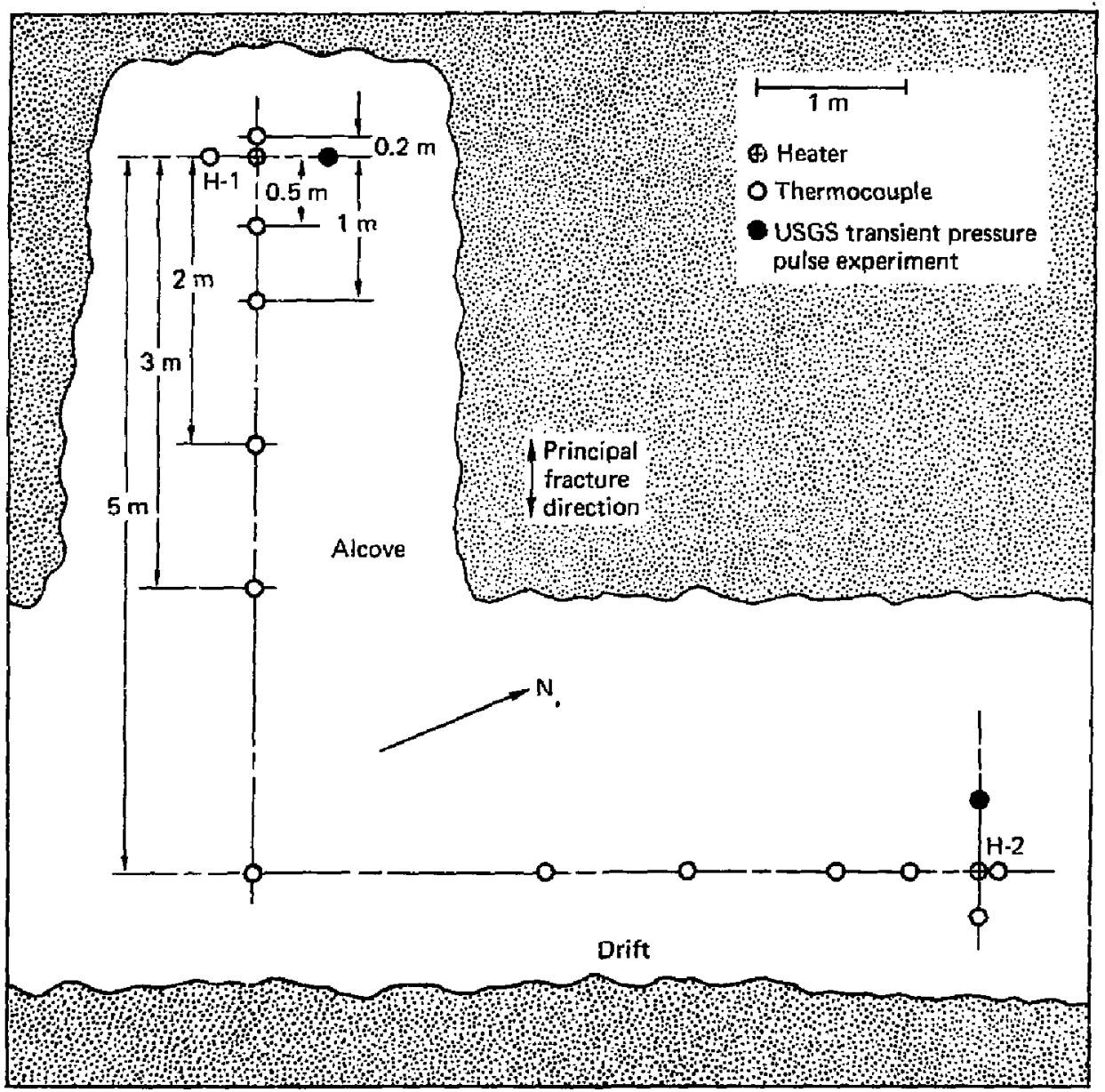

Figure 1. Plan viaw of Henter Test No. 1 layout, $420 \mathrm{~m}$ level, Climax granite (note that location dimengions for drift holes are the sume as these for alcove holes). 
shock effects and deep enough so that, within the 60 - to 70-day time duration of the tests, no significant heat would be lost to the drifts.

The test was planned for initial operation at a constant power level followed by superposed power fluctuations. The test objective was the highest power level consistent with a heater teruperature near $600^{\circ} \mathrm{C}$ at steady state, which turned out to be $3.7 \mathrm{~kW}$. An early power-off cycle was introduced because of an etactrical short, so the test plan was adjusted to give a final totel average power of $3.7 \mathrm{~kW}$, but with superposed power fluctuations. This allowed a fleld check on thermal diffusivity, which has a strong effect on temperature for short time periods but not at long time periods.

Thermocouples were mounted on the heaters and in the 48-mm-diam thermocouple holes (Fig. 1). The rock-measuring thermocouples were silver-soldered into copper pins, which in turn were spring-mounted on a stainless steel space frame, fou: to an assembly. For insertion, the copper pins were coated with

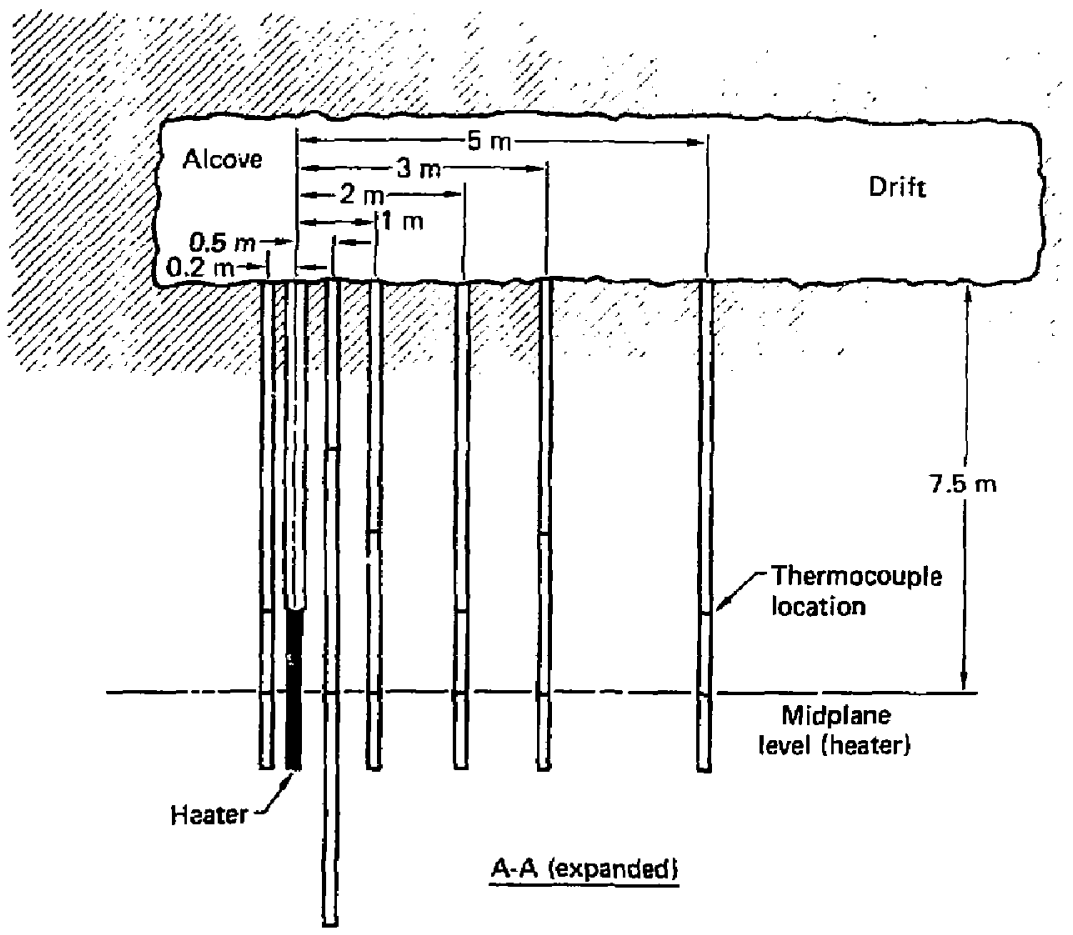

Flgure 2. Verticet ecction along ateove test array, Heater Test No. 1, Climax granite. 
thermal-conducting cement, and were then lowered in a withdrawn state and forced into contact with the hole walls once in place. This arrangement worked satisfactorlly and allowed us to withdraw the thermocouple assemblies to be reconfigured below packers for the permeability tests.

Although the heater test has not been formally documented, more details may be found in Refs. 2 and 3.

\section{Initial Scoping Calculations}

The initial scoping calculations were done usi ag available liter tture values of thermal properties for input. The calculation involved superposition and integration in time and space of the analytical solution to the point source equation

$$
T=\frac{Q}{4 \pi k x} \text { erfe } \sqrt{\frac{r^{2}}{4 k t}} .
$$

where $T=$ temperature; $Q=$ power; $k=$ thermal conductivity; $r=$ distance; $k=$ thermal diffusivity; and $t=$ time. For most calculations, the $3-\pi$ heater was represented as an array of 100 point sources. During the initial scoping calculations, it was always anticipated that two- or three-dimensional finitedifference calculations would be run with a code such as TRUMP, ${ }^{4}$ but this was based on an anticipated need to handle variable and nonlinear thermal conductivity and diffusivity. As will. be described, we found that the field results could be well approximsted using anaiytic calculations with constant values of thermal conductivity and diffusivity.

The initial scoping calculations (Fig. 3) usea a thermal conductivity $k$ of $2.5 \mathrm{~m} / \mathrm{m} \cdot \mathrm{K}$, a diffusivity $K$ of $1.0 \mathrm{~mm}^{2} / \mathrm{s}$, and a heater power level of $3 \mathrm{~kW}$. These calculations showed that in four weeks the rock would be approaching steady-state temperature to a distance of $1 \mathrm{~m}$, and that several months would be required for a rise of a few degree Celsius at $5 \mathrm{~m}$. Thus, the test layout was confined to a 5-m uistance (Figs. 1 and 2 ).

Results and Initigl Auglysis:

Thermal profiles in the granite were measured at 52 points at ranges from 0.27 to $5 \mathrm{~m}$ from the heaters, although for most of the tests, only about 20 


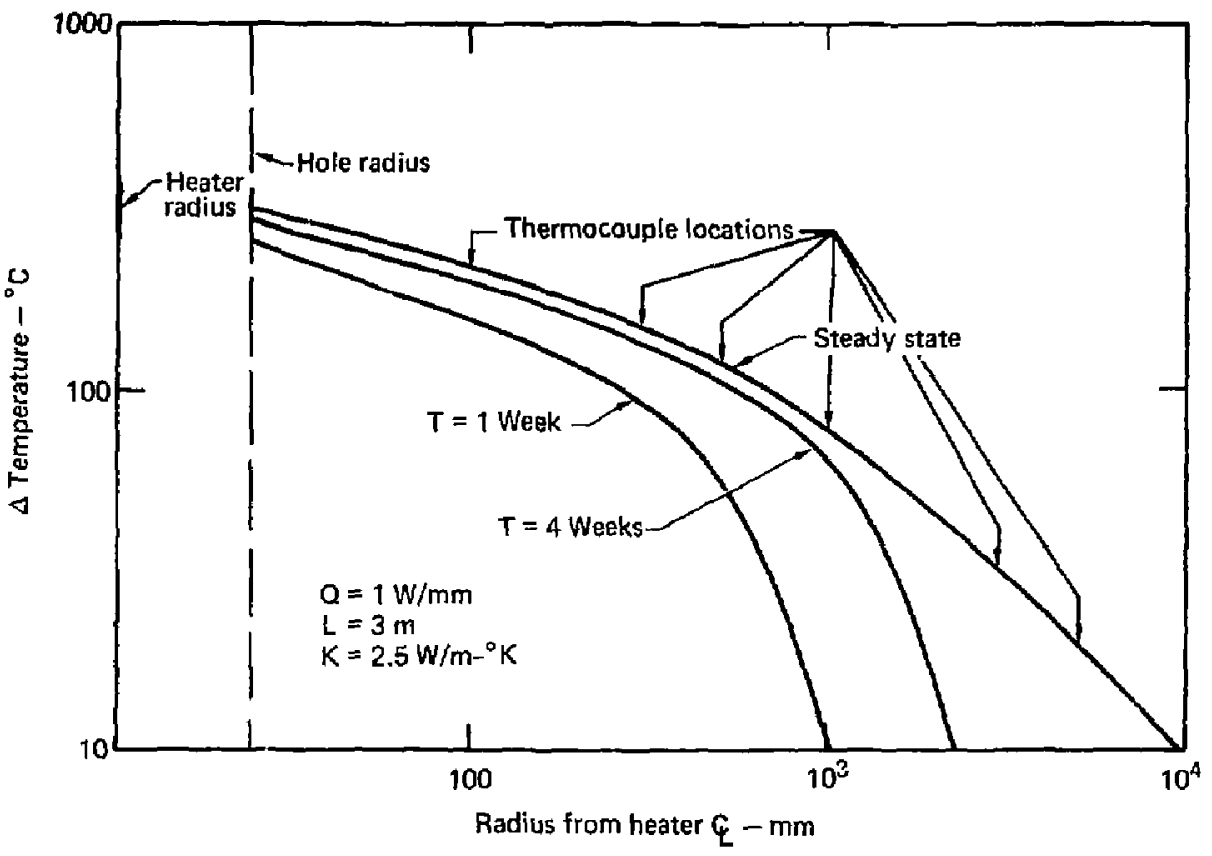

Figure 3. Temperature-distance therrial profiles for various times, Heater Test No. 1 scoping calculations.

channels recorded significant temperature increases. At the time the test was initiated, a two-dimensional, radial-symmetry TRUMP problem had not been set up for several reasons: we had mo data on thermal conductivity of climax granite as a function of temperature, and the set-up of the problem was a complex task. Computational personnel assigned to the task were making numerous analytic calculations to refine projected test times, power histories, and other support to the fielding. Thus, Initial data became available without the finite-difference capability, and natural curiosity led us to attempt a match with analytic calculations. An iterative series of simple calculations led to the input parameters $k=3.05 \mathrm{~W} / \mathrm{m}^{\circ} \mathrm{K}$ and $k=1.23 \mathrm{~mm} / \mathrm{s}$ for the actual heater length of $2.9 \mathrm{~m}$. These constant values gave good matches both close and far (relatively) from the beater (Figs. 4 and 5). Thurefore, throughout the test we continued to use the simpler calculational method for test control and inftial analysis. 


\section{Posttest Evaluation}

After the test, we had access to values of the change in thermal conductivity for climax granite core samples that were taken during construction of the test. ${ }^{5}$ These data showed a decline from about 3.5 to $3.7 \mathrm{~W} / \mathrm{m} \cdot \mathrm{K}$ at ambient temperature to about 3.1 at $200^{\circ} \mathrm{C}$ (projected). The average slope of these data was input as a linear function starting with an ambient temperature conductivity of $3.0 \mathrm{w} / \mathrm{m}^{\circ} \mathrm{K}$ into the TRUMP code in an axisymmetric two-dimensional

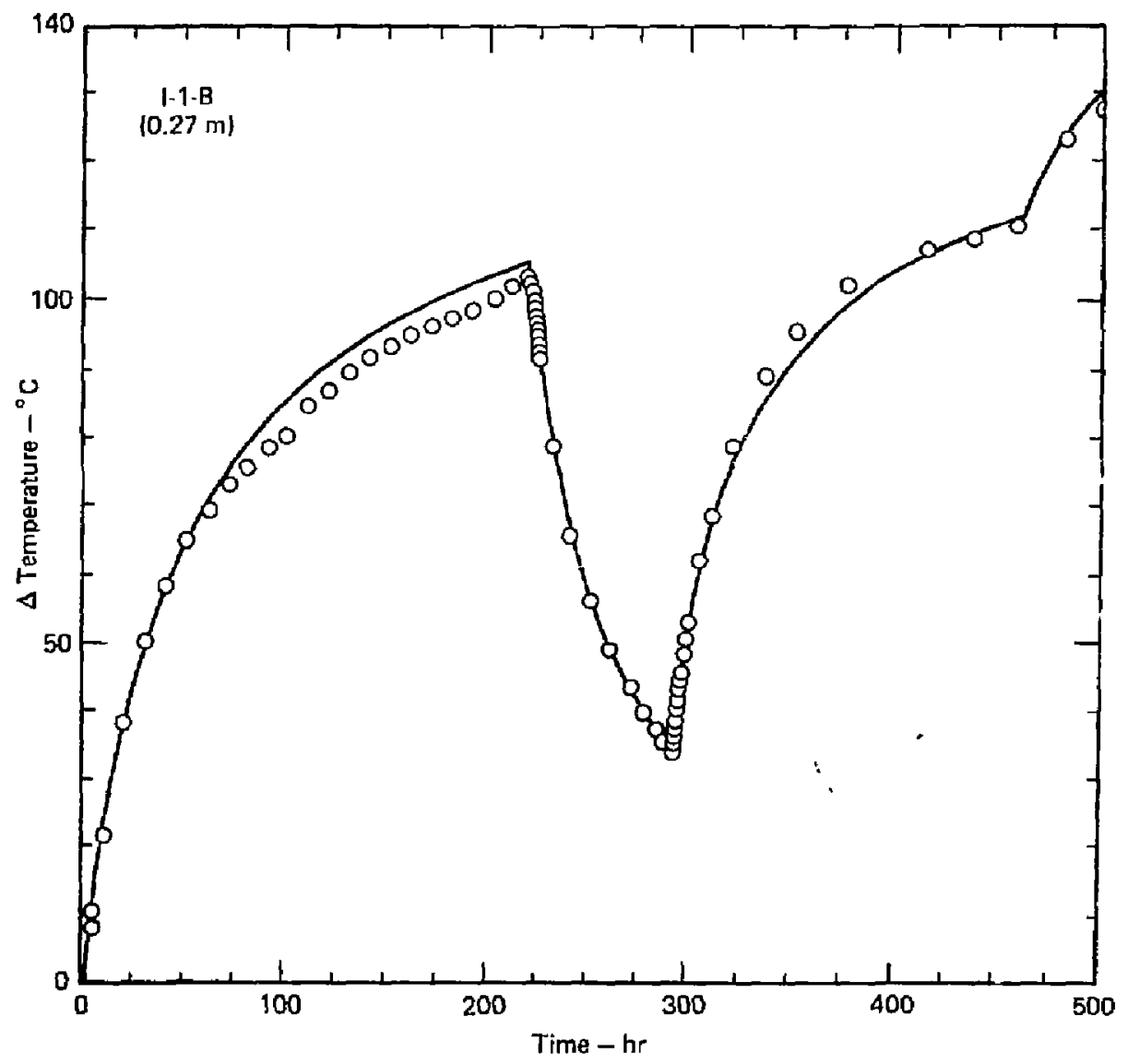

Figure 4. Comparinon of calculatad (solid line) and measured (circles) temperalures for slosest thermocouple $(0.27 \mathrm{~m}$ ) from the $\mathrm{H}-1$ heater. 


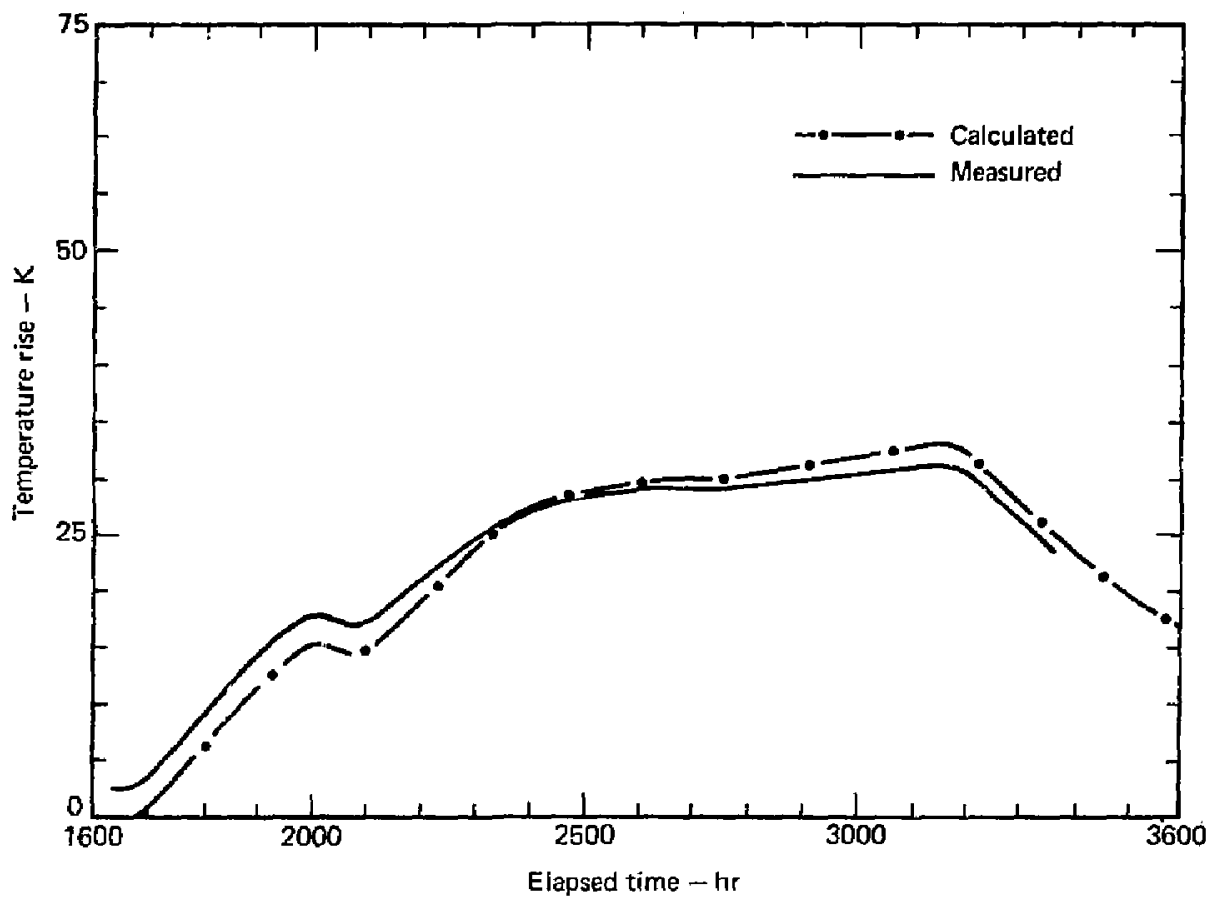

Figure 5. Comparison of calculated with measured temperature rise for moderate $(1.79 \mathrm{~m})$ distance themocouple from the $\mathrm{H}-2$ heater.

calculation. Prior to that, comparative calculations had shown Thump to give identical resuits to the analytic solutions at the sale of the illustrations that follow,

A comparison between a constant $k$ and variable $k$ calculation both with IRUMP) is shown in Fig. 6. We have no measurements on the borehole rock surface, which is calculated for illustration. However, the maximum difference between the two calculations for 0.27 distance, our closest data point is less than $15^{\circ} \mathrm{C}$. And at $1.15 \mathrm{~m}$ distance, the two caiculations are indistinguishable at this scale.

The original scoping calculations were based on an average value of thermal conductivity of $2.6 \mathrm{~W} / \mathrm{m} \cdot \mathrm{K}$ at $20^{\circ} \mathrm{C}$ for 14 samples of Climax granite but not from the heater test Iocation. ${ }^{6}$ The range of values for these samples was 2.3 to $3.4 \mathrm{~W} / \mathrm{m} \cdot \mathrm{R}$. Because of the known decline in thermal conductivity $w i t h$ increasing temperature, a constant value of 2.5 was selected for the scoping 


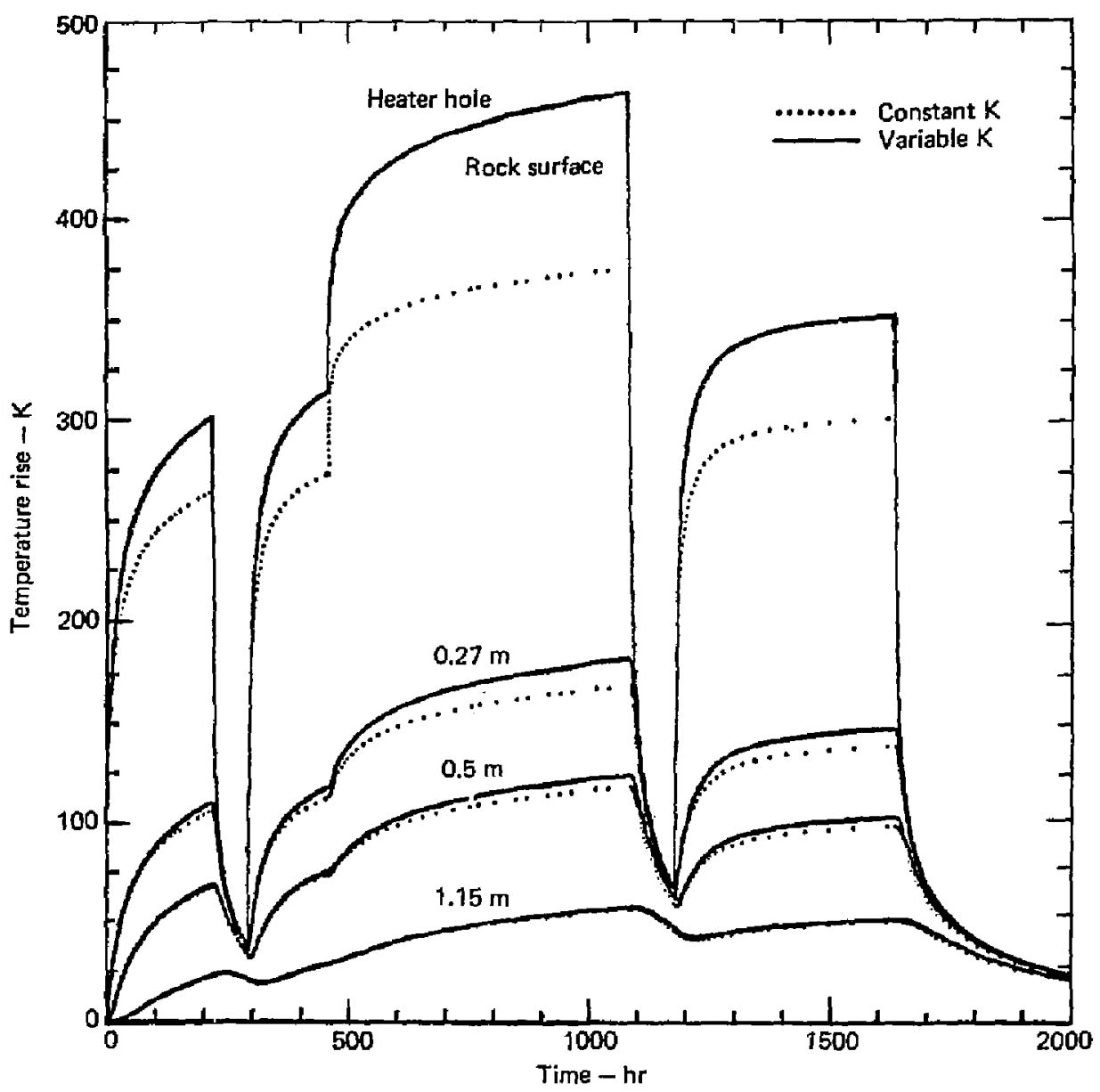

Figure 6. Comparison of TRUMP calculations with constont vs variable thermal conductivity for $\mathrm{H}+1$ tett power history.

calculations. Pogt-test meagurements on core taken from the ieater test site Itself have all given values in the range of 3.4 to $3.7 \mathrm{w} / \mathrm{m} \cdot \mathrm{K}$ at $20^{\circ} \mathrm{C}$, with decline in conductivity to 3.2 at $200^{\circ} \mathrm{C}$. As pointed out previously, the best 1terative fit to the data used a constant thermal conductivity of $3.05 \mathrm{w} / \mathrm{m} \cdot \mathrm{K}$.

In general, heat adaorption and transport by water played only a omall role in the thermal profiles. For those locations $0.5 \mathrm{~m}$ or less distant from the heater, the rock texperatuze exceeded the boiling point of water at some 
time during the test. For those locations, a deflection in the measured temperature-time history curve can be associated with the refluxing of a small anount of water in the thermocouple holes. The subsequent data curves then parallel the slope of the calculated curves. The rock was reheated for the permeability tests with no measurable change in behavior (the heating cycle was closely calculated and monitored using the same $3.05 \mathrm{w} / \mathrm{m} \cdot \mathrm{R}$ conductivity, with excellent matching).

\section{Permeahility Test Data}

Following operation of heater test No. 1 for thermal measurements, the layout was modified for in situ measurement of permeability as a function of rock temperature. ${ }^{3}$ Although these results were not nodeled either before or after the test, the rock behavior is reported here for possible relevance to understanding other behavior, such as fracture closure.

By careful control of heater power, plateaus of essentially constant rock temperature were maintained long enough for transient pertieability measurements to be made as a function of temperature (Table 1). Consistently, the measured permeability declined with increasing temperature to below the measurement capability of the system and then recovered to about the pretest values.

TABLE 1. In situ rock permeability as a function of rock temperature, climax granite.

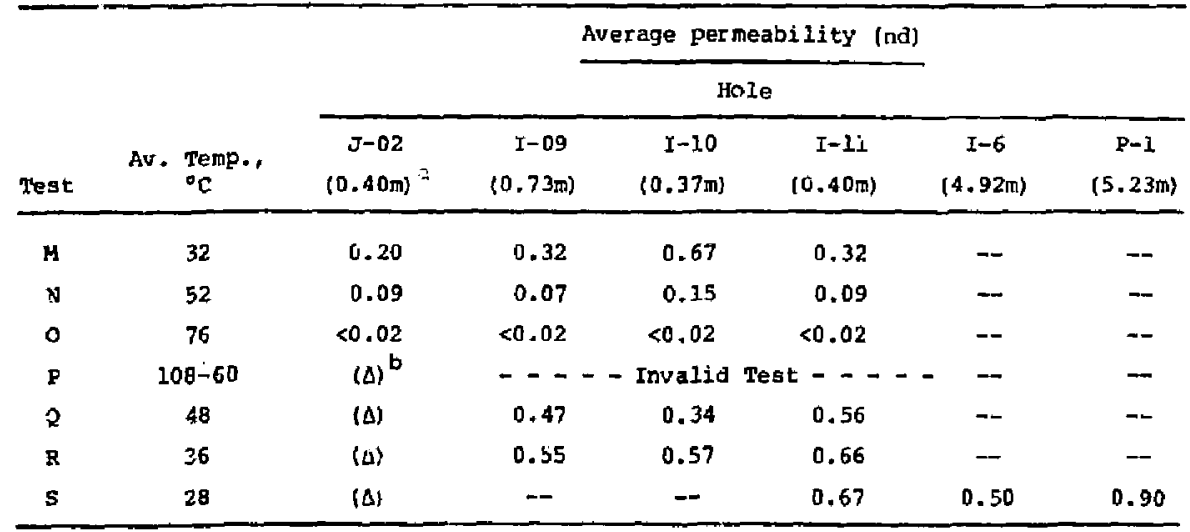

Distance from centerline of heater hole.

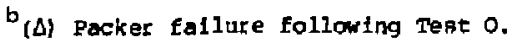




\section{Conclusions}

The rock temperature for a given applied heat load at a point in time and space can be adegiately modeled with simple analytic calculations involving superposition and integration of numerous point source $\equiv$ lutions. The input, For locations beyond about a meter from the source, can be a constant thermal conductivity and diffusivity. The value of thermal conductivity required to match the field data is as much as $25 \%$ different from laboratory-measured values. Therefore, unless come to understand the mechanisms for this ji.:ference, a simple in situ test will be required do obtain a value for final repository design. Some sensitivity calculations have shown that the temperature field is about ten times more sensitive to conductivity than to diffusivity under the test conditions. The orthogonal array was designed to detect anisotropy. Hfter considering all error sources, anisotropic efforts in the thermal field were Itss than 5 to I08.

\section{RESPONSE OF CLIMAX GRAMITE TO MINING}

As noted earlier, LLL is engaged in construction and operation of a spent Fuel Test in the Climax granite. I As a pretest background measurement, stress changes and displacements resulting from mining of the canister storage arift were monitored from the adjacent heater drifts immediately prior to, juring, and after mining. There are several reasons for making these measurements. Pirst, stress and displacement measurements will be made throughout the duration of the Spent Fuel Test, and it is desirable to have background data prior to heating of the rock. Second, it has been asserted that the relative magritudes of stress changes and displacements caused by mining are either large or small compared with heating of the rack. In such a situation, actual fielo measurements are helpful.

\section{Scoping Calculations}

To plan the stress and displacenent instrumentation, scoping calculations were made using the ADINA code, ${ }^{7}$ a fintte-element program fo: Automatic Dynamic Incremental Nonlinear Analysis. The ADINA code was designed to perform 
linear and mnlinear analyses in the design of structures. It has one-, two-, and three-dimensional capabilities and can handle nonlinear ities that result. E:om large displacements, large strains, or nonlinear material behavior. The material deswiptions available inelude: lsotropic or or thotropic In elastic, isotropic thermal-elastic, elastic-plastic, thermo-elastic-plasticcreep, or a user-specified curve description model. Effectively, the code solves incremental nodal point equilibrium equations for an assemblage of nonlinẹar finite elements.

The ADINA calculations made for the excavation phase of the spent-fuel test were planar, representing a plane section thraugh the canister and heater drift excavations. The material was assumed to be isotropic and elastic with constant (not temperature or pressure dependent) elastic modulus of $7 \times 10^{6}$ psi (47.63 GRa) and a poisson's ratio of 0.2 . The boundary conditions assumed a preexisting vertical stress of $\mathrm{ogh}$ and a horizontal stress of $0.8 \mathrm{pgh}$. The grid used in the calculations has BlO nodal points and 710 four-node elements. This grid is for half of the excavation with a vertical line of symmetry passing through the center of the canister arift.

Figure 7 (a) shows the close-in portion of the grid prior to excavation with the outline of the elements that will be removed during the excavation calculations. Figure $7(b)$ shows the displaced grid following excavation of the side (heater) drifts. The original grid position is shown with the broken lines. The difference between the displaced position and the original position represents the displacement of the material as a result of the mining operation. There are two scales for the figures, one for the grid distance and one for the displacement. F:om Fig. $7(b)$, the maximum displacement caused by heater arift excavation is shown to se of the order of one millimeter. Figures $7(c)$ and 7 (d) show the displaced grids following excavation of only the upper level of the canister orift and the total excavation of both levels, respectively. Maximum displacements from all the excavations is about two uillineters. Sinilar graphs (not included here) show the calculated alteration of the stress field around the excavations.

Ins'rumentation.

Based on these scoping calculations, stress and displacement instrumentation was emplaced from two locations along the heater drifts prior to mining the canister storage drift. Figure $B$ is the plan view of this instrumentation 


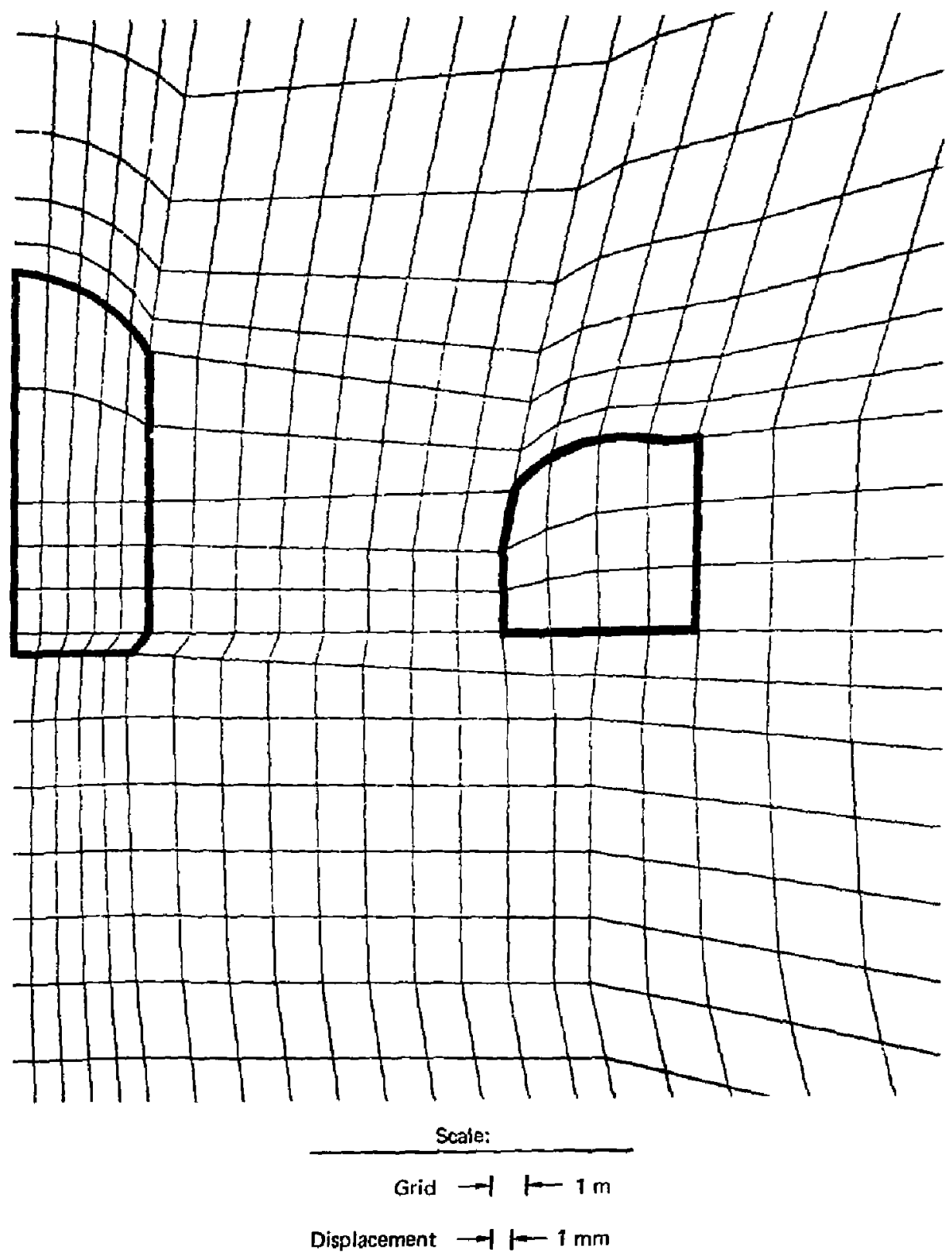

Figure 7(a). Colculational grid bofore excevation. Bold lines indicate the approximate drift outline. 


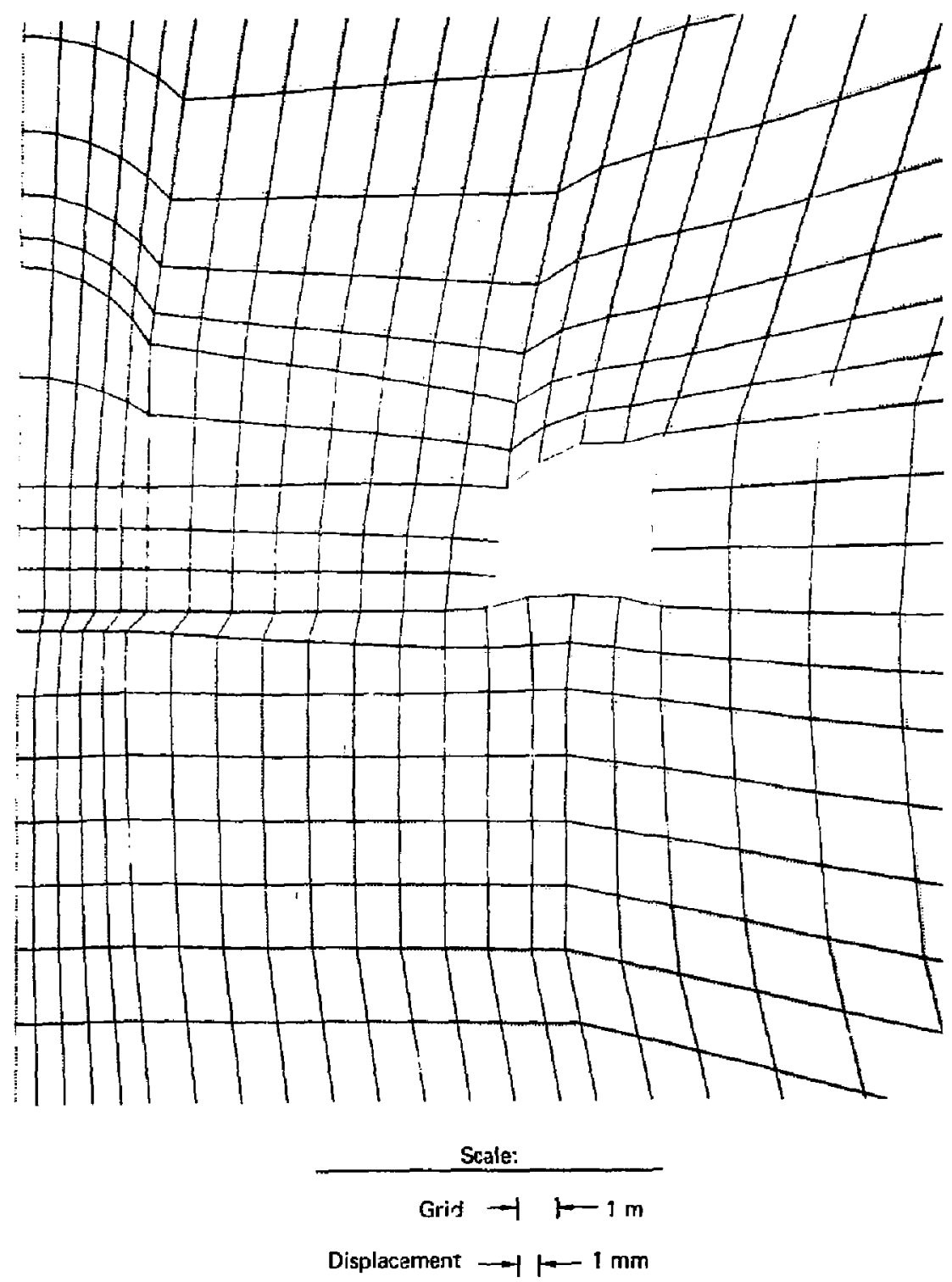

Figure $7(b)$. Calsulational grid following excavation of the side drifte. The dotted lines indieate the position of the original grid $l_{1}$ shown in Figure $\left.7(a)\right)$. 


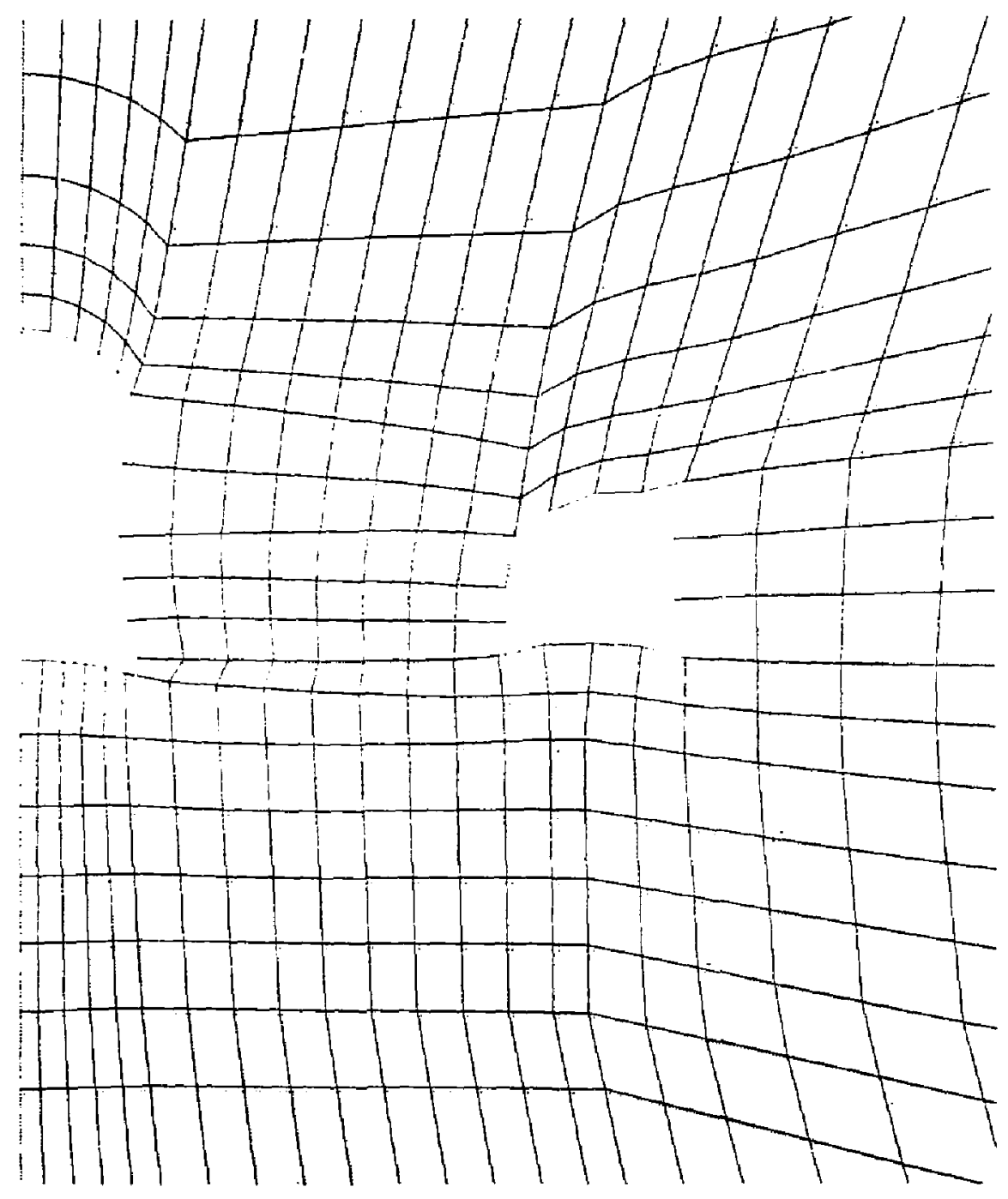

Scale:

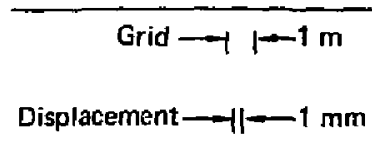

Figure $\boldsymbol{z}$ (c). Displaced grid following exchvation of the upper and lower lovels of the canister dritt and the side drift. The dotted lines indicate the position at the original grid lahown in Figure 7 (d)l], 


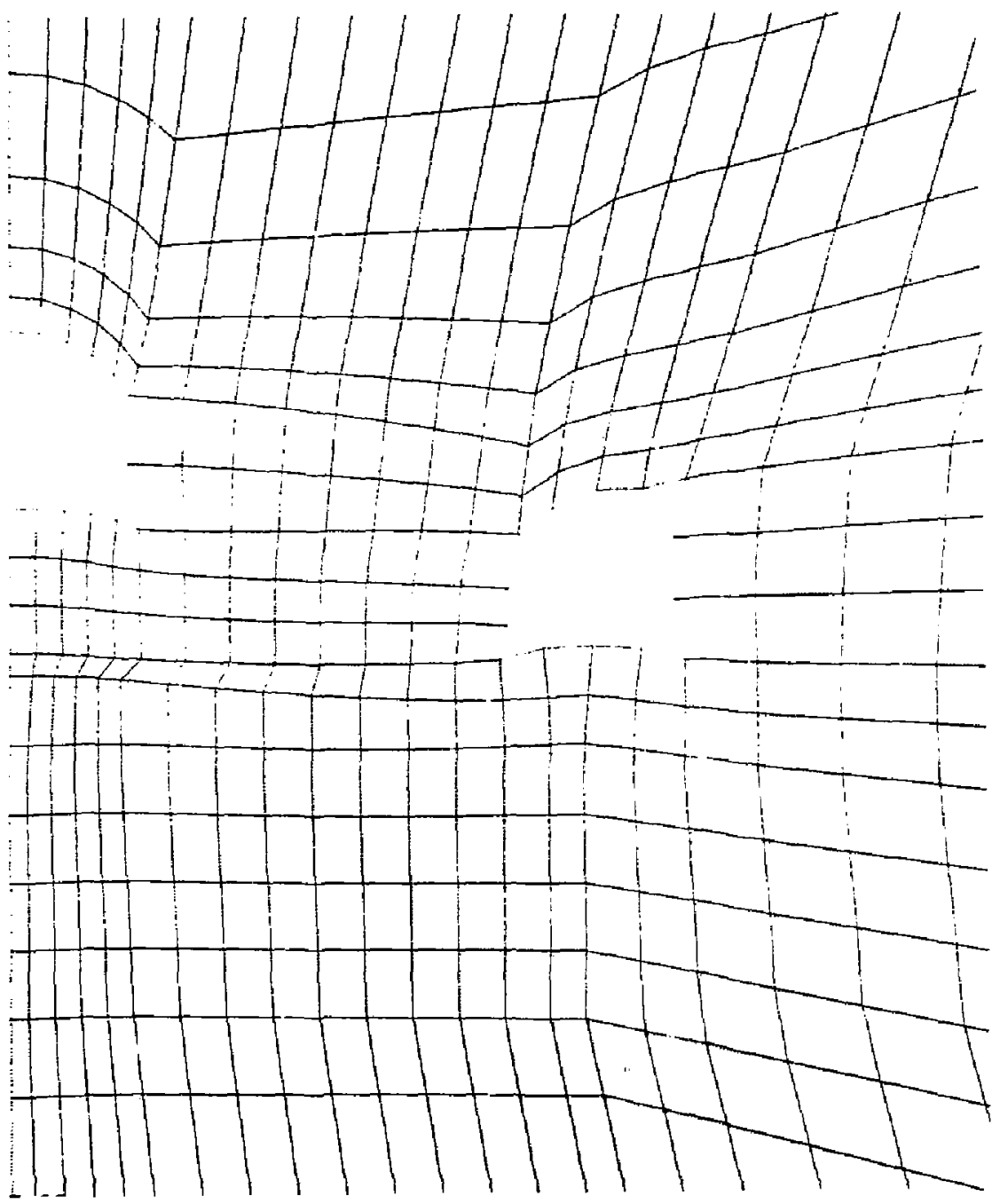

Scale:

Grid $-1-1 \mathrm{~m}$

Displacement $\rightarrow-11-1 \mathrm{~mm}$

IFigure 7(d). Displaced grid lollowing excevation of the canister drift and the side drift. The dotted lines indicate the position of the original grid [shown in Figure 7(a)]. 


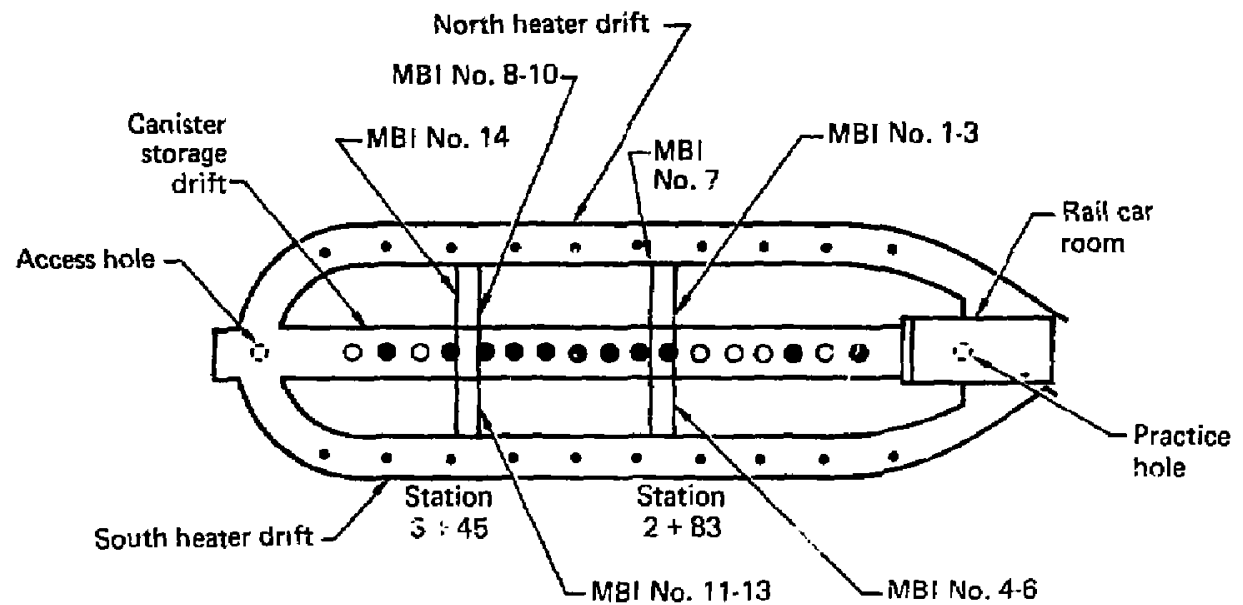

Figure 8. Plan view of mine-by experiment, Climax grenite spent fuel tests, NTS.

and Fig. 9 shows a schamatic cross-section. The specific locations of each anchor foint or stress meter were selected based on analysis of core from the dxill holes. Convergence was aIso measured by taping through MBI 7 and MBI 14, which are horizontal holes connecting the heater arifts (Fig. 8). The in situ state of stress in the roek was measured southward from the South Heater Drift near station $3+00$, between the two instrumentation clusters. U.S. Geological survey personnel used the rock overcore method for these measurements.

Preliminary Data

One of the simplest methods of displaying the Iarge amount of data taken is to compare calculated and measured values for the data stations. Figures 10 and 11 show such a comparlson for the electronically read extensometers at stations $2+83$ and $3+45$. The values in parentheses are calculated; all others are measured. Negative values indicate shortening between the anchors and the extensometer head; positive values indicate lengthening.

Pigures 12 and 13 show data from manually read tape-extensoneter measurements. The same conventions are used as for Figs. 10 and 11 .

Table 2 shows a comparison of measured and calculated changes in vertical stress as a result of mining. VSM 1 and VSM 2 are both located in the same drili hole; 3 is in a nearby arill hols. Although the calculations differ 


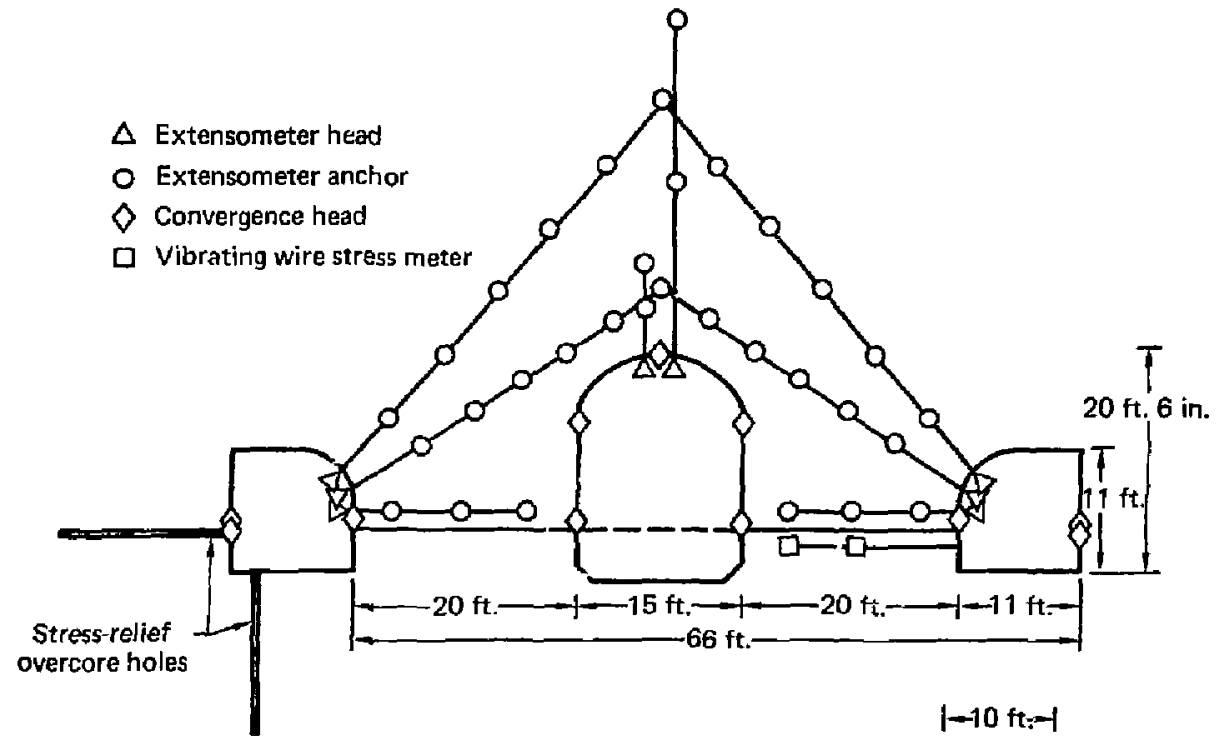

Figure 9. Schematic cross-section af spent fuel test showing relative locations of mine-by instruments.

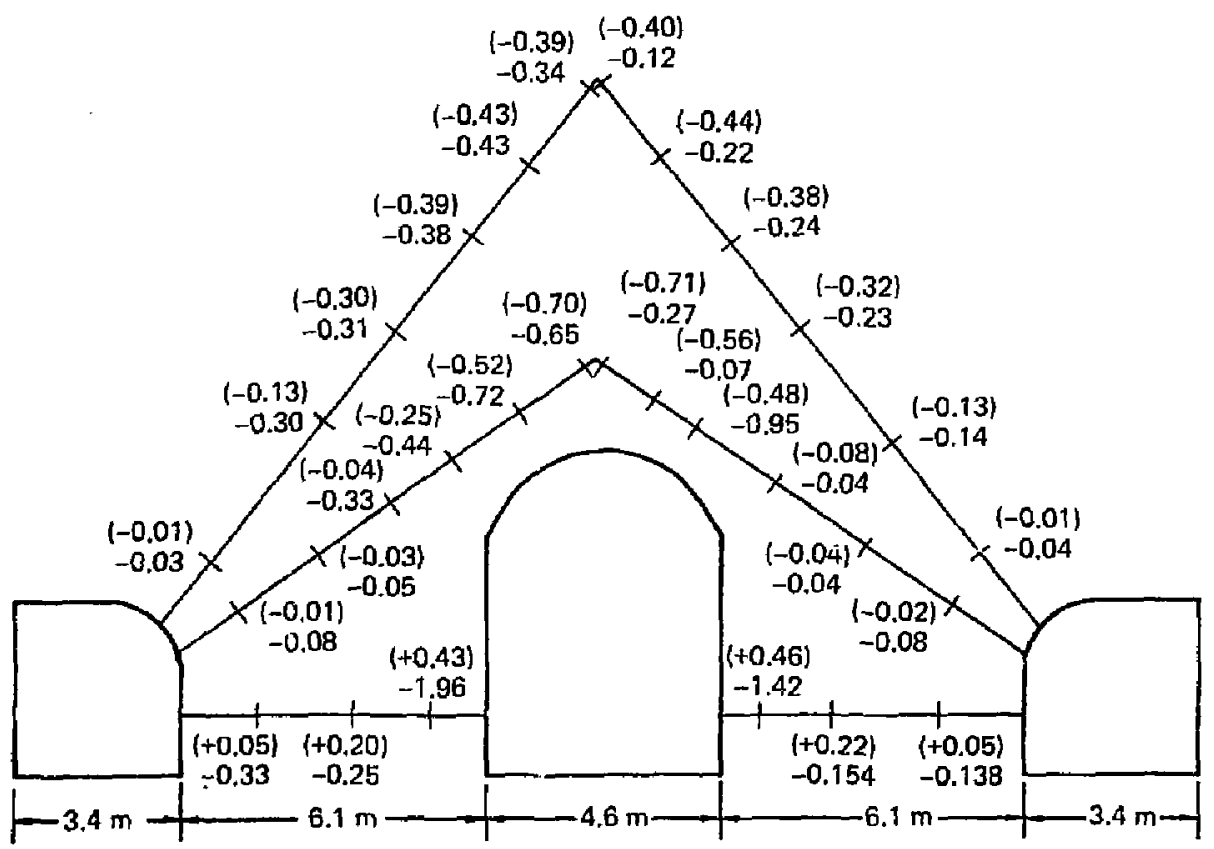

Figure 10. Mining-induced relative displecements $(\mathrm{mm})$ in the less-jointed rock $(\sim 2+\mathrm{B3})$. 


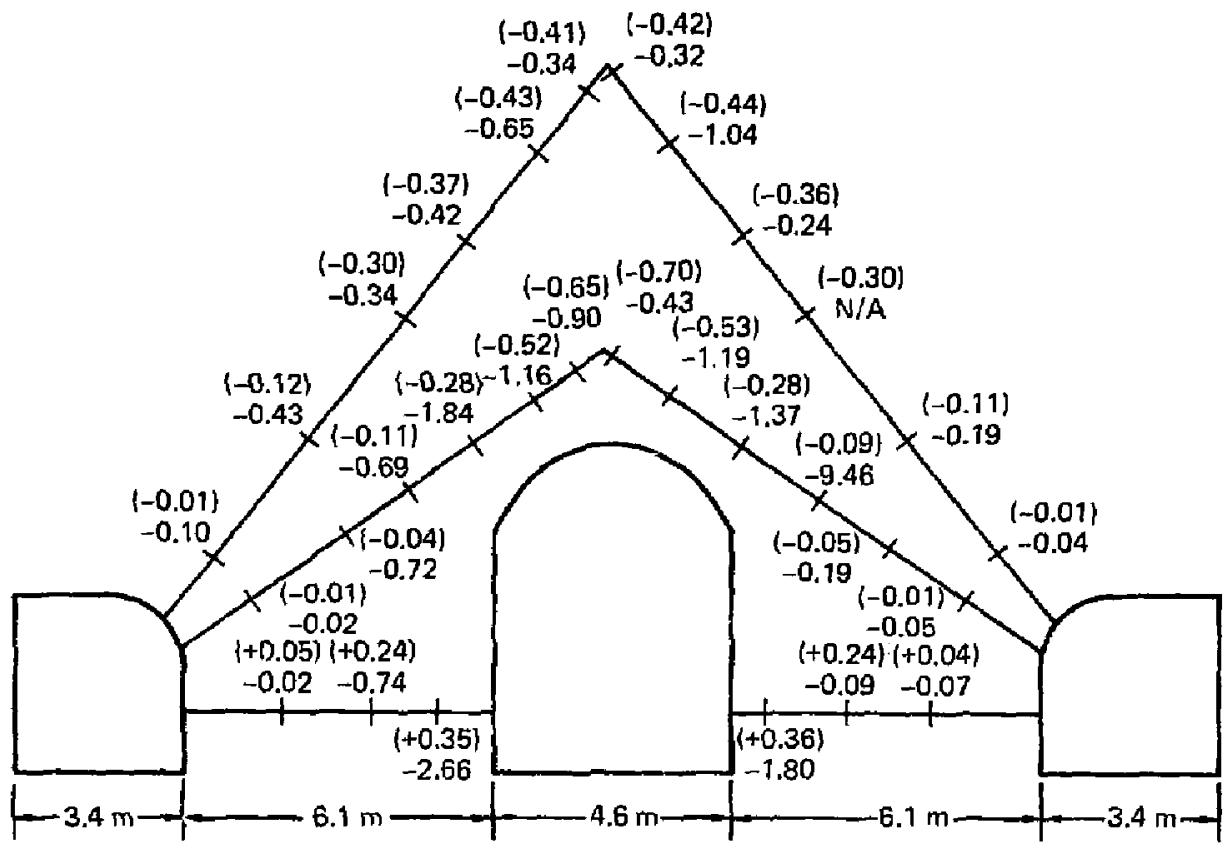

Figure 11. Mining-induced relative displacements $(\mathrm{mm})$ in the more-jointed rock $(-3+45)$.

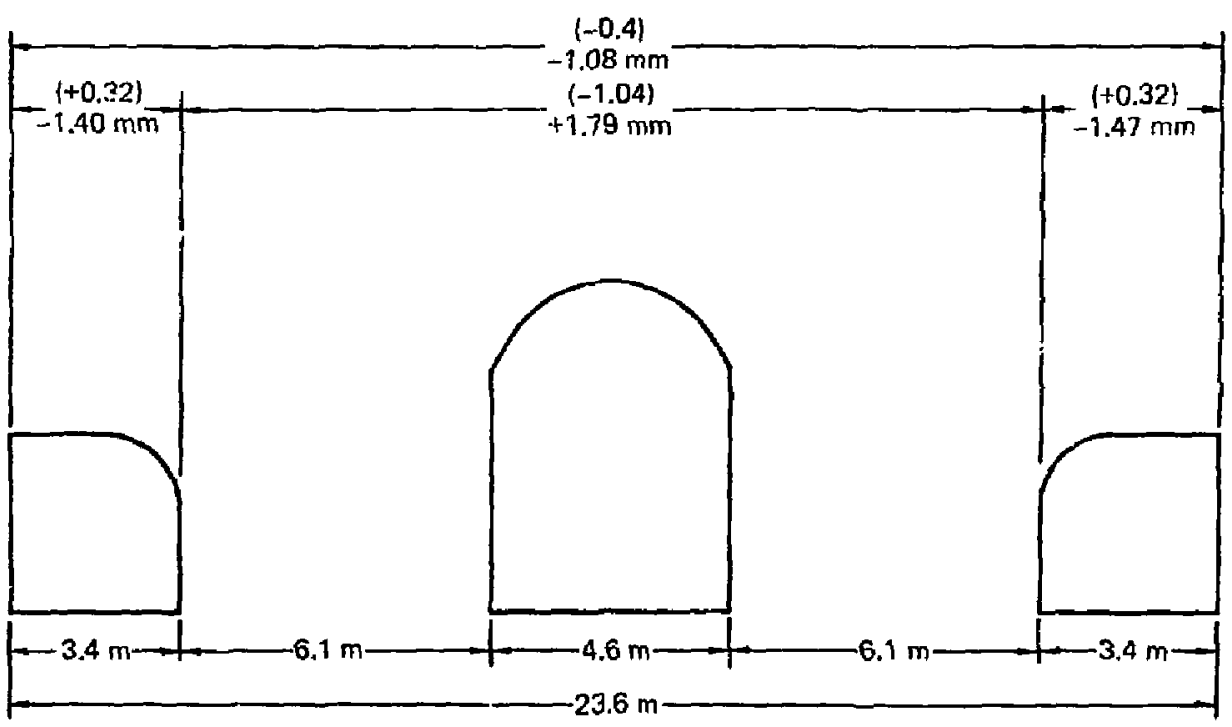

Flase 12. Mining-indured horizontul relative displosements in the less-jointed rock $(\sim 2+83)$. 
widely, all calculated values are different in sign and widely separated in magnitude from the measured values.

It should be enphasized that these are very preliminary results. We present these unevaluated data in the hope that they will be of some benefit to this workshop.

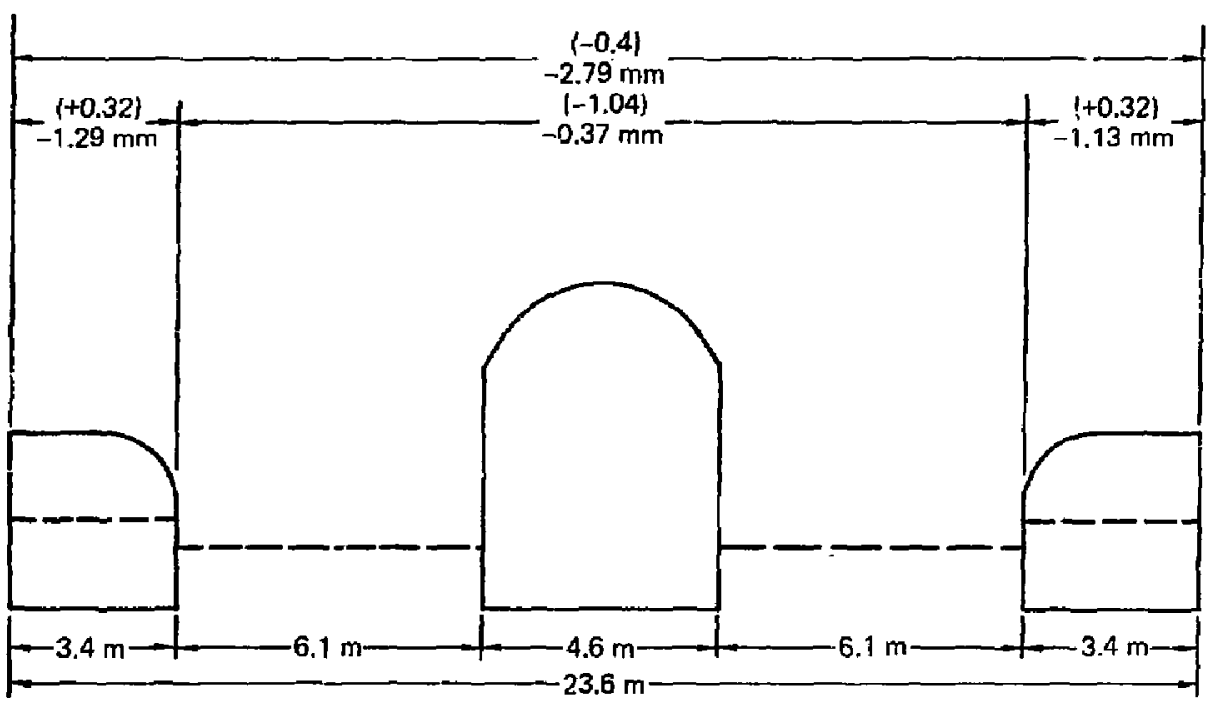

Figure 13. Mining-induced horizontal relative displacer. vef ' $s$ in the more-jointed rock $\{\sim 3+45\}$.

TABLE 2. Comparison of measured and calculated changes in vertical stress as a result of mining, sFT-C.

\begin{tabular}{|c|c|c|c|c|c|c|}
\hline $\begin{array}{l}\text { StresB } \\
\text { neter } \\
\text { number }\end{array}$ & $\begin{array}{l}\text { Dist, fron } \\
\text { canister } \\
\text { drift, ft }\end{array}$ & $\begin{array}{c}\text { vsy } \\
\text { reading, } \\
\text { poi }\end{array}$ & $\begin{array}{c}\text { Calc. } \\
\text { 11, psi }\end{array}$ & $\begin{array}{l}\text { Calc. } \\
* 2, \text { psi }\end{array}$ & $\begin{array}{l}\text { Calc. } \\
\text { 3, psi }\end{array}$ & $\begin{array}{l}\text { Calc. } \\
\text { 4. psi }\end{array}$ \\
\hline $\operatorname{vsy} 1$ & 3 & -1405 & 292 & 514 & 630 & 792 \\
\hline $\operatorname{van} 2$ & 10 & -196 & 396 & 697 & 390 & 490 \\
\hline VSH 3 & 3 & -1020 & 292 & 514 & 630 & 792 \\
\hline
\end{tabular}

Note: $E=8.8 \times 10^{6} \mathrm{pgi}$ for Vay calculation

Calc. 1 aseumes $E=5.0 \times 10^{6}$ psi

calc. 2 convertg calc. 1 to $\mathrm{E}=8.8 \times 10^{6} \mathrm{psi}$

Calc. 13 assumes $E=7.0 \times 10^{6} \mathrm{psi}$

calc. 14 converts Calc. $\$ 3$ to $\mathrm{E}=8.6 \times 20^{6} \mathrm{pgi}$ 
TASLE 3. Sumary of USGS overcore stress values.

\begin{tabular}{lcc}
\multicolumn{1}{c}{ Orientation } & $\begin{array}{c}\text { Assuned stress } \\
\text { for calculations, } \\
\text { psi }\end{array}$ & $\begin{array}{c}\text { Calculated from } \\
\text { measured stress, } \\
\text { psi }\end{array}$ \\
\hline Parallel to tunnels & 1264 & 563 \\
Perpendicular to tunnels & 1264 & 1279 \\
Vertical & 1580 & 1148 \\
\hline
\end{tabular}

As noted above, the scoping calculations assumed a vertical stress equal to overburden load, and a horizontal stress equal to 0.8 of overburden. The USGS overcore stress determinations gave different values, as sumarized in Table 3. All of the other input data were taken from measurements on intact core and therefore do not represent the rock mass properties. Given the unrealistic input, the fact that rock is known not to be a continuum, and the fact that the calculational mesh did not represent the as-built drift geometry, one would not expect these calculations to predict rock behavior. Before publishing the results, we intend to improve the calculations by using the iss-built geometry and more realistic input, although we currently plan to use the continuum code.

\section{Comclusions}

Lawrence Livermore Laboratory his documented the response of the Climax gran1 te to mining and has made a prelininary comparison with the instrumentation scoping calculations. These data will form a baseline for analysis and evaluation of measurements during the thermal phase of the climax granite Spent Fuel Test.

\section{REFERENCES}

1. L. D. Raspott, L. B. Ballou, R. C. Carlson, D. N. Montan, T. R. Butkovich, J. E. Duncan, W. C. Patrick, D. G. Hilder, W. G. Brough, and M. C. Mayr, Technlcal Concept for Test of Geologle Storage of Spent Reactor Fuel in the Climax Granite, Nevada Test Site, Lawrence Livermore Laboratory, Rept. UCRL-52796 (1979). 
2. L. D. Ramspott, Technical Editor, Waste Isolation Profects--FY 1977, Lawrence Liver nore Laboratory, Rept. UCRL-50050-77 (1978) .

3. L. D. Ramspott, Scientific Editor, Waste Isolation Projects--IY I978, Lawrence Livermore Laboratory, Rept. UCRL-50050-78 (1979).

4. A. I. Edwaras, TRUMP; A Computer Progran For pransient and steady-State Temperature Distributions in Multidimensional Systems, Lawrence Livermore Laborabory, Rept. UCRL-14754, Rev . 3 (1972) .

5. R. Iingle and $H$. Pratt, Iaboratory Measured Material properties of Granodiorite, Climax stock, Nevada l'est site, Terra-Tek informal report TR 78-47 (August 1978).

6. F. Maldonado, Summary of the Geology and Physical Properties of the Climax Stock, Nevada Test Site, U.S. Geological Survey Open-File Report 77-356 (1977).

7. K. J. Bathe, ADINA, A Finite Element Erogram for Automatic Dynamic Incremental Nonitinear Analysis, Massachusetts Institute of Technology, Cambridge, Mass., Rept. 82448-1 (September, 1975, reissued May, 1976). 